\title{
Influence of biologically active substances, chemicals and growth regulators on diseases of conifers in urban conditions
}

\author{
Lyudmila Lyashcheva*, Aleksandr Lyashchev, and Irina Prok \\ State Agrarian University of the Northern Trans-Urals, 625003, 7, Republic str., Tyumen, \\ Tyumen region, Russian Federation
}

\begin{abstract}
The objects of study were coniferous plants aged from 6 to 10 years. The study involved such plants as Siberian spruce (Pícea obováta), prickly spruce Hoopsi (Picea pungens Hoopsii), western thuja Smaragd (Thuja occidentalis Smaragd), thuja western Brabant (Thuja occidentalis Brabant). The subject of the study was the pathological symptoms manifested on the aboveground plant organs. The plants were planted in 2015 at the age from 6 (thuja Smaragd and thuja Brabant) to 10 (prickly spruce and Siberian spruce) years. The studies were conducted from May 2016 to September 2018 inclusive. During the initial examination, which was carried out on May 28, 2016, on all conifers, there was a loss of decorativeness, partial premature drying of shoots and falling of needles. When using biological products, a persistent stimulating effect is very noticeable - the general condition of conifers improves, this makes it possible to recommend tank mixtures for use, the composition of which is less toxic. Thuja Brabant turned out to be the most unresponsive to drug treatment.
\end{abstract}

\section{Introduction}

Plants in the city not only decorate streets and courtyards, but also have a significant impact on the microclimate of green areas. In summer, tree plantations reduce the temperature of the ambient air and the underlying surface, protect from wind and direct sunlight, increase air humidity, and conifers, among other things, are excellent noise mufflers. Leaves and needles are capable of trapping and settling dust, absorbing pollutant gases and other harmful impurities from the air. Phytoncides secreted by plants have the ability to cleanse the air from bacteria and saturate it with light negative ions. Of the coniferous plants growing in the northern forest-steppe, thuja takes the first place in phytoncides, followed by pine, spruce, fir and juniper.

However, not every coniferous plant is easily adaptable and can grow for a long time and retain its decorative effect in urban conditions. The urbanized environment is distinguished not only by the originality of the main environmental factors, but also by specific man-made influences that inhibits plants. That is why, in urban conditions, conifers

\footnotetext{
*Corresponding author: liashheva53_72@rambler.ru
} 
are characterized by high growth rates at a young age (up to 15-20 years) and early aging (the life span of plants is reduced by 3-4 times), which is due to the intensive expenditure of vital resources for adaptation to unusual environmental conditions [1,6]. Rapid aging of trees occurs due to the influence of air pollution, soil salinity, anthropogenic factors and many others. In this regard, non-infectious diseases develop, plants weaken and rapid aging occurs. At present, due to the large scale of construction and landscaping of territories in our city, one of the main tasks of phytopathology is to increase the resistance of tree and shrub species in the city to diseases [7].

The purpose of the study is to study new methods of protecting coniferous plants from diseases and to identify the most effective ones in urban conditions.

\section{Methods}

The objects of study were coniferous plants aged from 6 to 10 years. The study involved such plants as Siberian spruce (Pícea obováta), prickly spruce Hoopsi (Picea pungens Hoopsii), western thuja Smaragd (Thuja occidentalis Smaragd), thuja western Brabant (Thuja occidentalis Brabant). The subject of the study was the pathological symptoms manifested on the aboveground plant organs.

The Tyumen region is located in the Trans-Urals zone in the basin of the lower reaches of the $\mathrm{Ob}$ and Irtysh rivers in the West Siberian lowland. The climate of the zone is sharply continental, characterized by cold, long winters and short, moderately hot summers. Unhindered penetration of cold Arctic air from the north and from dry Kazakhstan causes sharp fluctuations in the weather and leads to its general instability [2].

Annual precipitation is $450 \mathrm{~mm}$, of which 224 falls during the growing season. The sum of effective temperatures above $+5{ }^{\circ} \mathrm{C}$ ranges from $1900-2050{ }^{\circ} \mathrm{C}$, and the duration of the period above $0{ }^{\circ} \mathrm{C}$ is 205-210 days. A stable snow cover is established on November 11 , and collapses on April 10, its maximum height is formed in March - $36 \mathrm{~cm}$, with $93 \mathrm{~mm}$ of water reserves in the snow. The depth of soil freezing is on average $108 \mathrm{~cm}$, but in some areas it reaches $250 \mathrm{~cm}$. The average July air temperature is $+13 \mathrm{oC}$ with a maximum of +36 and $+38 \mathrm{oC}$, January $-19 \mathrm{o}$ with a minimum of $41 \mathrm{oC}$. According to long-term average data, the last spring frost falls on May 21, but it is possible until June 12, and the first autumn frost - from August 19 to September 22. The frost-free period lasts 114 days. The hydrothermal coefficient (1.1) indicates a satisfactory moisture supply to plants.

Tyumen - 3 USDA-zone of frost resistance, northern forest-steppe with an absolute minimum temperature from -40.0 to $-34.5^{\circ} \mathrm{C}[1,2]$. However, in the conditions of Tyumen, some plants of the 1-4th zone (frost resistance zones according to Gerd Krüssmann) feel comfortable, which winter at temperatures not lower than $-34.4^{\circ} \mathrm{C}$, for example, varieties of western thuja and others.

The study was carried out on an experiment plot in the Emergencies Ministry park at the address: Tyumen, 4030 Let Pobedy Str., where the studied plants were planted considering the recommendations for their agricultural technology. All plants were purchased from nurseries in Tyumen. The total area of the territory is 0.532 hectares. The terrain is flat.

The assessment of the state of plants was carried out visually by a point method in accordance with the "Methodological recommendations for assessing the viability of trees and the rules for their selection and appointment for felling and replanting" [6]. Needle diseases were determined according to I.G. Semenkova, E.S. Sokolova [11].

For each plant species, the average score of plant viability was calculated within calculation. Twice a year, at the beginning and at the end of the growing season, a description of the condition of conifers was made. The final registration of the state of plants was carried out in August of each year. 
The treatments were carried out in accordance with the Sanitary Rules and Norms SanPiN 1.2.2584-10 (as amended on June 10, 2016), considering the safety requirements for use of pesticides and agrochemicals within the boundaries of settlements [9].

For the treatment of conifers from diseases, we used preparations recommended for use on these crops and a tank mixture created at the State Agrarian University of the Northern Trans-Urals.

For study, we took a mixture of drugs previously used to combat diseases of conifers in the city of Tyumen - Bordeaux liquid $3 \%$ + Zircon, P (0.1 g/l), Fundazol, SP $(500 \mathrm{~g} / \mathrm{kg})+$ Epin-Extra, P (0.025 g/l), Tilt, EK (0.4 \%) + Epin-Extra, P (0.025 g/l).

The tank mixture was made up of a fungicide of microbiological origin, which was used as a concentrate of the culture liquid Bacillus subtilis - Fitosporin-M strain $26 \mathrm{D}$ with a titer of at least 100 million spores and bacteria/g produced by OOO NPO BashInkom; growth regulator and immunostimulant in the form of AGAT 25 preparation containing the waste products of bacteria Pseudomonas aureofasciens (alpha-alanine $-80 \mathrm{mg} / \mathrm{kg}$, o-glutamic acid $-70 \mathrm{mg} / \mathrm{kg}$, 3-indoleacetic acid $-18 \mathrm{mg} / \mathrm{kg}$ ) produced by Edna LLC. The tank mix also contains balanced starting doses of macro- and microelements, which are part of the complex microelement fertilizer TENSO cocktail containing a set of microelement salts: calcium $(\mathrm{Ca})-2.57 \%$ chelated form of EDTA, boron (B) - $0.52 \%$, copper $(\mathrm{Cu})-0.53 \%$ chelated EDTA, iron $(\mathrm{Fe})-2.1 \%$ chelated EDTA, manganese $(\mathrm{Mn})-2.57 \%$ chelated EDTA, molybdenum (Mo) $-0.13 \%$, zinc $(\mathrm{Zn})-0.53 \%$ chelated form of EDTA with the addition of magnesium sulfate (MgSO4) $0.7 \%$. An alcoholic solution of balsam poplar buds extract with a dry matter content of $34 \%$, as well as $25 \%$ vermicompost extract BKK-9 preparation was used as a bioactive additive in the tank mixture.

Working solutions of all drugs and the tank mixture were compiled immediately before use by mixing aqueous concentrates of the drugs in such a way that their concentration in the working solution corresponded to those recommended by the manufacturers and permitted for use in the Russian Federation. Poplar bud extract was used at a concentration of $0.5 \mathrm{~g} / \mathrm{l}$ of the working solution in accordance with the recommendations of E.V. Kalyuta et al. [5]. Analysis of the biological activity of poplar bud extract, given in the paper of E.V. Isaeva et al, testifies to the prospects of its use as an immunomodulator and nonspecific stimulator of growth and development [6].

Plants were treated by spraying them with a manual pneumatic sprayer of the Avtomax type with a total volume of 10 liters. Average liquid consumption is $0.4 \mathrm{l} / \mathrm{min}$., maximum working pressure is $0.4 \mathrm{MPa}$ ( 4 bar) nozzle MR 1.0. The consumption rate is $0.2-0.51$ of the working solution per plant, depending on its size and the density of the needles in such a way that all the outer parts of the plant are covered with liquid. Control plants were treated with clean tap water.

\section{Results}

The plants were planted in 2015 at the age from 6 (thuja Smaragd and thuja Brabant) to 10 (prickly spruce and Siberian spruce) years. The studies were conducted from May 2016 to September 2018 inclusive. During the initial examination, which was carried out on May 28,2016 , on all conifers, there was a loss of decorativeness, partial premature drying of shoots and falling of needles.

Having studied the lesions of the studied coniferous plants, we obtained the following results. The following non-communicable diseases were identified: sunburn, chlorosis and frost cracks (Fig. 1).

Some species and varieties of conifers have low frost resistance, so sunburn is inevitable. The largest number of sunburns was noted in thuja western Brabant, $24.2 \%$, 
lower in thuja Smaragd $-12.4 \%$, in thorny spruce $-2.4 \%$. Sunburns were not observed in Siberian spruces.

Chlorosis was detected in $2.6 \%$ of thujas Smaragd, in $2.4 \%$ of thujas Brabant and in $1.2 \%$ of Siberian spruces. Shallow frost cracks were found in $1 \%$ of Siberian spruces and in $1.1 \%$ of Brabant thujas.

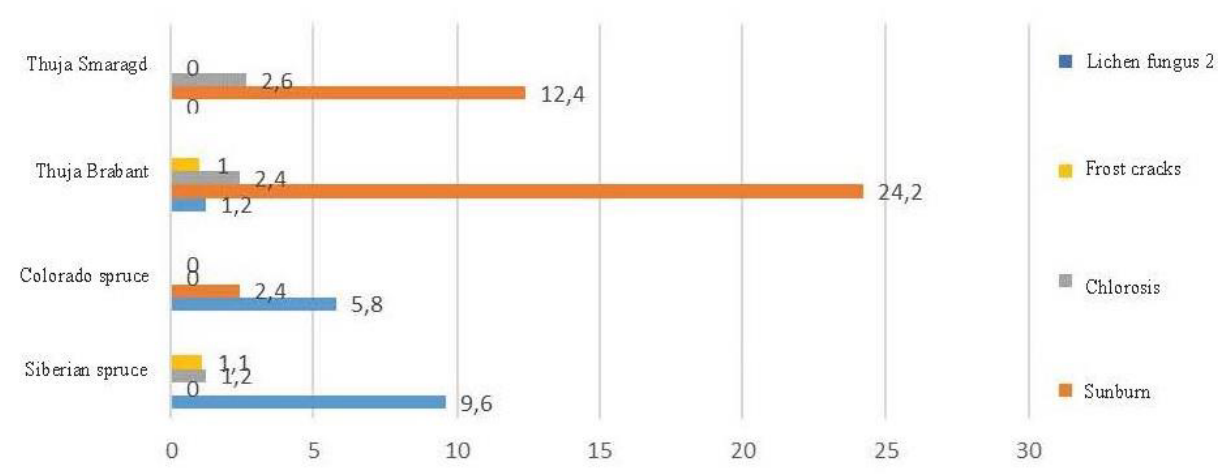

Fig. 1. Percentage of incidence of non-infectious diseases of the studied coniferous plants in the territory of the Emergencies Ministry park, Tyumen, 2016.

When assessing trees with signs of damage to needles and leaves, the following degrees of damage were established: 0 points - healthy plantations - no signs of damage; 1 point weak damage - up to $25 \%$ of needles and leaves are affected; 2 points - medium damage $25-50 \%$ of needles and leaves are affected; 3 points - severe damage - over $50 \%$ of needles and leaves are affected. All surveyed trees had lesions from 0 to 1 points.

Determination of diseases and their causative agents was carried out using determinants.

When processing the data obtained, the following tasks were identified: to calculate, based on the results of the survey, the proportion of trees of various categories of state in the surveyed plantation (in percent) and to assess the sanitary state of this territory one year after planting.

The calculation of the state of the plantation was carried out according to the formulas:

$\mathrm{P}=\mathrm{n} \times 100: \mathrm{N}$, where $\mathrm{P}$ is the prevalence of the disease, $\% ; \mathrm{n}-$ the number of damaged and dried plants, pcs.; $\mathrm{N}$ is the total number of recorded plants, pcs.

In total, 57 damaged and withered plants were found on the investigated plot, with a total number of plants on the plot of 89 .

$\mathrm{P}=57 \mathrm{x} 100: 89=64 \%$

Therefore, the total infection rate of the surveyed area was $64 \%$.

During the growing season, treatments were carried out according to the schedule of treatments (Table 1).

Table 1. Schedule of treatments with drugs of various effects to reduce the incidence of diseases of coniferous crops in the Park of the Ministry of Emergencies in Tyumen, 2016-2018.

\begin{tabular}{|c|c|c|c|c|c|c|c|c|c|}
\hline \multirow[b]{2}{*}{ Drug } & \multirow{2}{*}{$\begin{array}{c}\text { Class of } \\
\text { chemical } \\
\text { composition }\end{array}$} & \multicolumn{6}{|c|}{ Processing (months) } & \multirow{2}{*}{$\begin{array}{c}\text { Total } \\
\text { treatmen } \\
\text { ts }\end{array}$} & \multirow{2}{*}{$\begin{array}{c}\text { What was } \\
\text { the } \\
\text { treatment } \\
\text { against }\end{array}$} \\
\hline & & 4 & 5 & 6 & 7 & 8 & 9 & & \\
\hline Control (water) & & 1 & 1 & 1 & 1 & 1 & 1 & 6 & $\begin{array}{l}\text { Sh, R, GDA, } \\
\text { O }\end{array}$ \\
\hline
\end{tabular}




\begin{tabular}{|c|c|c|c|c|c|c|c|c|c|}
\hline $\begin{array}{l}\text { Bordeaux liquid } 3 \%+ \\
\text { Zircon, } \mathrm{P}(0.1 \mathrm{~g} / \mathrm{l})\end{array}$ & $\begin{array}{l}\text { Copper group } \\
\text { Hydroxycinna } \\
\text { mic } \\
\text { acids }\end{array}$ & 1 & & & & & 1 & 2 & GDA, Sh \\
\hline $\begin{array}{l}\text { Fundazol, SP }(500 \mathrm{~g} / \mathrm{kg}) \\
+ \text { Epin-Extra, P }(0.025 \\
\mathrm{g} / \mathrm{l})\end{array}$ & $\begin{array}{l}\text { Benzimidazol } \\
\text { es } \\
\text { Brassinolides }\end{array}$ & & 1 & & & & & 1 & $\mathrm{Sh}, \mathrm{R}, \mathrm{GDA}$ \\
\hline $\begin{array}{l}\text { Tilt, KE }(0.4 \%)+\text { Epin- } \\
\text { Extra, P }(0.025 \mathrm{~g} / \mathrm{l})\end{array}$ & \begin{tabular}{|l} 
Triazoles \\
Brassinolides
\end{tabular} & 1 & & & & 1 & & 2 & $\mathrm{R}, \mathrm{Sh}$ \\
\hline $\begin{array}{l}\text { Tank mix (Fitosporin M, } \\
\text { AGAT-25 K, TENSO } \\
\text { cocktail, BKK-9, poplar } \\
\text { bud extract) }\end{array}$ & \begin{tabular}{|l|} 
Bacillus \\
subtilis \\
bacteria, \\
Pseudomonas \\
aureofasciens, \\
trace \\
elements, \\
aqueous \\
extract of \\
cattle \\
vermicompost \\
alcoholic \\
extract of \\
poplar buds
\end{tabular} & & 1 & 1 & 1 & 1 & & 4 & $\begin{array}{l}\text { Sh, R, GDA, } \\
\text { O }\end{array}$ \\
\hline
\end{tabular}

Legend: GDA — fungi deuteromycetes and ascomycetes (fusarium, verticillosis, vascular diseases); R — rust; $\mathrm{Sh}$ - pine-leaf cast; O — sunburns.

All preparations participating in the experiment belonged to different groups according to the class of chemical structure, according to the number and time of treatments.

So, Bordeaux liquid belongs to the group of copper-containing preparations, zircon to hydroxycinnamic acids, basezole to the benzimidazole group, tilt to the triazole group, epin-extra to brassinolides. The tested tank mixture included: biological preparation phytosporin M, AGAT-25 K, TENSO cocktail, as well as bacteria Bacillus subtilis, Pseudomonas aureofasciens, microelements, alcoholic extract of poplar buds and extract of cattle biohumus preparation BKK-9. Such complex formulations were supposed to determine a wide spectrum of action of multipurpose drugs and growth regulators in the program for the restoration and cultivation of conifers in an urban environment.

The number of treatments was consistent with the instructions for use.

We also calculated the effectiveness of our therapeutic and prophylactic treatments with the studied drugs in points of viability. The results are shown in Figures 2-4. 
The highest efficiency of treatment-and-prophylactic treatments in the case of infestation with ordinary shute was in the variant treated with the tank mixture, the difference with the control was 1.04 points.

The studied preparations against powdery mildew and rust have shown good efficacy. They showed efficiency two times higher than in the control.

The prickly spruce was affected by common shute and rust, neither fusarium, nor powdery mildew was found. The effectiveness of the preparations was 1.5 times higher when treated with mixtures: Bordeaux liquid + zircon; foundationol + epin-extra and tilt + epin-extra and 2 times higher when processing with a tank mixture.

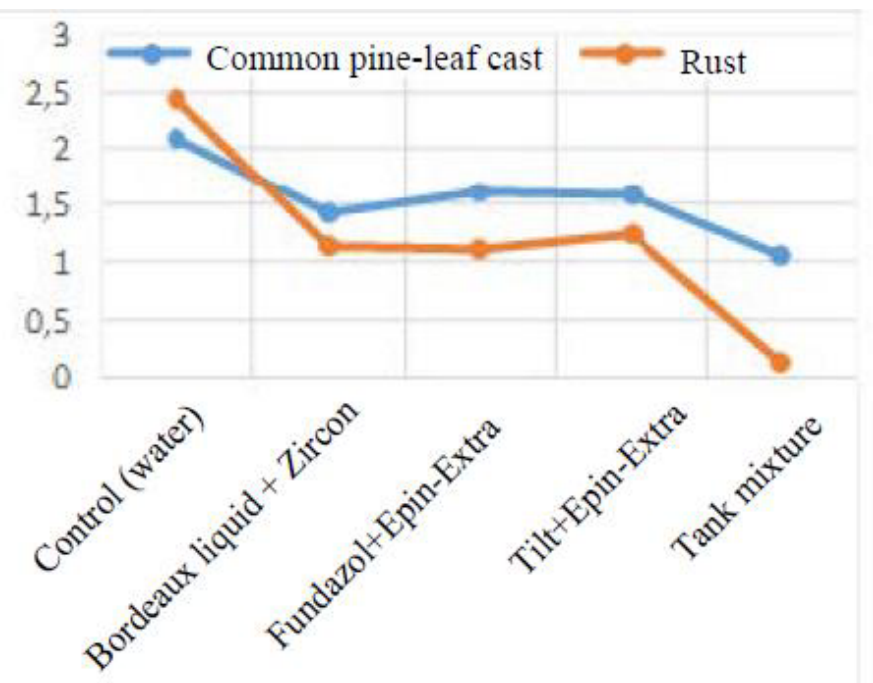

Fig. 2. The effectiveness of therapeutic and prophylactic treatments for Siberian spruce (in points of viability).

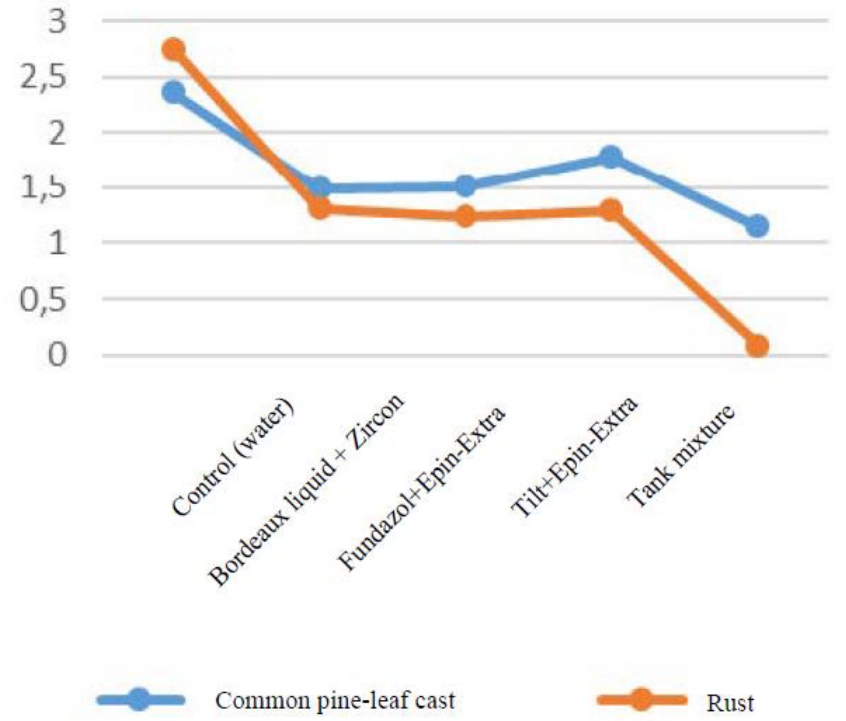

Fig. 3. The effectiveness of treatment-and-prophylactic treatments for prickly spruce (in points of viability). 


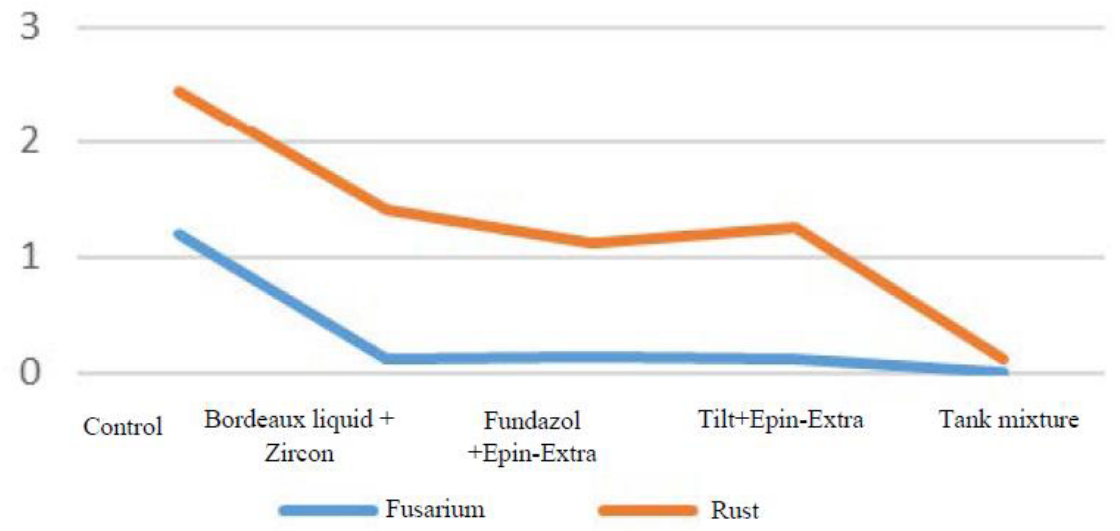

Fig, 4. The effectiveness of therapeutic and prophylactic treatments for western thuja (Brabant and Smaragd) (in points of viability).

The results that we received as a result of treatments with different effects and chemical composition on biometric indicators of seedlings of Siberian spruce, prickly spruce (blue) and Thuja Brabant are presented in Tables 2-4.

Biometric measurements show that Siberian spruce seedlings have grown significantly over the three years of research, and treatment with drugs had a significant impact on the growth and development of seedlings. The tank mixture had an especially strong influence. The treatments helped to reliably increase the trunk height by $131 \mathrm{~cm}$, the trunk diameter by $12.2 \mathrm{~cm}$ and the crown diameter by $32 \mathrm{~cm}$.

Table 2. Biometric indicators of Siberian spruce seedlings, 2016 - 2018.

\begin{tabular}{|c|c|c|c|c|c|c|c|c|c|}
\hline \multirow[b]{3}{*}{ Drug } & \multicolumn{9}{|c|}{ Siberian spruce } \\
\hline & \multicolumn{3}{|c|}{ Tree height, $\mathrm{cm}$} & \multicolumn{3}{|c|}{ Trunk diameter, cm } & \multicolumn{3}{|c|}{ Crown diameter, cm } \\
\hline & 2016 & 2018 & $\begin{array}{c}+,- \text { to } \\
\text { control } \\
\text { of } \\
2018\end{array}$ & 2016 & 2018 & $\begin{array}{c}+,- \text { to } \\
\text { control } \\
\text { of } \\
2018\end{array}$ & 2016 & 2018 & $\begin{array}{c}+,, \text { to } \\
\text { control } \\
\text { of } \\
2018\end{array}$ \\
\hline $\begin{array}{l}\text { Control } \\
\text { (water) }\end{array}$ & 134 & 294 & - & 6.6 & 10.1 & - & 113 & 164 & - \\
\hline $\begin{array}{l}\text { Bordeaux } \\
\text { liquid } 3 \% \\
+ \text { Zircon, } \\
\text { P }(0.1 \mathrm{~g} / \mathrm{l})\end{array}$ & 142 & 358 & +64 & 8.2 & 14.6 & +4.5 & 132 & 175 & +11 \\
\hline $\begin{array}{l}\text { Fundazol, } \\
\mathrm{SP}(500 \\
\mathrm{g} / \mathrm{kg})+ \\
\text { Epin- } \\
\text { Extra, } \mathrm{P} \\
(0.025 \mathrm{~g} / \mathrm{l})\end{array}$ & 148 & 396 & +102 & 9.8 & 18.2 & +8.1 & 141 & 181 & +17 \\
\hline $\begin{array}{l}\text { Tilt, KE } \\
(0.4 \%)+ \\
\text { Epin- } \\
\text { Extra, P } \\
(0.025 \mathrm{~g} / \mathrm{l})\end{array}$ & 152 & 398 & +104 & 8.4 & 19.3 & +9.2 & 156 & 184 & +20 \\
\hline $\begin{array}{l}\text { Tank mix } \\
\text { (Fitosporin } \\
\text { M, }\end{array}$ & 164 & 425 & +131 & 15.7 & 22.3 & +12.2 & 163 & 196 & +32 \\
\hline
\end{tabular}




\begin{tabular}{|c|c|c|c|c|c|c|}
\hline \multirow[t]{2}{*}{$\begin{array}{l}\text { AGAT-25 } \\
\text { K, TENSO } \\
\text { cocktail, } \\
\text { BKK-9, } \\
\text { poplar bud } \\
\text { extract) }\end{array}$} & & & & & & \\
\hline & 18.2 & 41.5 & 1.04 & 1.64 & 17.8 & 20.1 \\
\hline
\end{tabular}

In prickly spruce (blue), the trend persisted, but the effect of the preparations was weaker and the Bordeaux mixture + zircon showed the lowest increase $-19 \mathrm{~cm}$ in trunk height, $4.1 \mathrm{~cm}$ in trunk diameter and $35 \mathrm{~cm}$ in crown diameter. While other drugs worked better and increased the indicators by 18 (tilt + epin-extra) and $30 \%$ (tank mix), respectively.

Table 3. Biometric indicators of prickly spruce seedlings (blue), 2016 - 2018.

\begin{tabular}{|c|c|c|c|c|c|c|c|c|c|}
\hline \multirow[b]{3}{*}{ Drug } & \multicolumn{9}{|c|}{ Colorado spruce (blue) } \\
\hline & \multicolumn{3}{|c|}{ Tree height, cm } & \multicolumn{3}{|c|}{$\begin{array}{c}\text { Trunk diameter, } \\
\text { cm }\end{array}$} & \multicolumn{3}{|c|}{ Crown diameter, $\mathrm{cm}$} \\
\hline & 2016 & 2018 & $\begin{array}{c}+,- \\
\text { to } \\
\text { con } \\
\text { trol } \\
\text { of } \\
201 \\
8\end{array}$ & 2016 & $\begin{array}{c}201 \\
8\end{array}$ & $\begin{array}{c}+,- \\
\text { to } \\
\text { con } \\
\text { trol } \\
\text { of } \\
201 \\
8\end{array}$ & 2016 & 2018 & $\begin{array}{c}+,- \\
\text { to } \\
\text { con } \\
\text { trol } \\
\text { of } \\
201 \\
8\end{array}$ \\
\hline $\begin{array}{l}\text { Control } \\
\text { (water) }\end{array}$ & 188 & 315 & - & 5.3 & 9.7 & - & 96 & 123 & - \\
\hline $\begin{array}{l}\text { Bordeaux } \\
\text { liquid } 3 \% \\
+ \text { Zircon, } \\
\mathrm{P}(0.1 \mathrm{~g} / 1)\end{array}$ & 287 & 334 & +19 & 7.4 & 13.8 & +4.1 & 123 & 158 & +35 \\
\hline $\begin{array}{l}\text { Fundazol, } \\
\mathrm{SP}(500 \\
\mathrm{g} / \mathrm{kg})+ \\
\text { Epin- } \\
\text { Extra, } \mathrm{P} \\
(0.025 \mathrm{~g} / \mathrm{l})\end{array}$ & 249 & 368 & +53 & 8.1 & 19.1 & +9.4 & 157 & 194 & +37 \\
\hline $\begin{array}{l}\text { Tilt, KE } \\
(0.4 \%)+ \\
\text { Epin- } \\
\text { Extra, } \mathrm{P} \\
(0.025 \mathrm{~g} / \mathrm{l})\end{array}$ & 226 & 372 & +57 & 7.9 & 19.5 & +9.8 & 149 & 189 & +66 \\
\hline $\begin{array}{l}\text { Tank mix } \\
\text { (Fitospori } \\
\text { n M, } \\
\text { AGAT-25 } \\
\text { K, } \\
\text { TENSO } \\
\text { cocktail, } \\
\text { BKK-9, } \\
\text { poplar bud } \\
\text { extract) }\end{array}$ & 241 & 412 & +97 & 8.5 & 23.7 & $\begin{array}{c}+14 . \\
0\end{array}$ & 161 & 205 & +82 \\
\hline NSR 05 & 24.4 & 32.7 & & 0.6 & 2.5 & & 17.1 & 22.4 & \\
\hline
\end{tabular}


Thuja Brabant turned out to be the most unresponsive to drug treatment. The increase in trunk height ranged from $9 \mathrm{~cm}$ (Bordeaux liquid + zircon) to $37 \mathrm{~cm}$ (tank mix). The rest of the options showed average gains. The bore diameter showed an increase from $107 \%$ when treated (Bordeaux fluid + zircon) to $125 \%$ when treated with a tank mixture. The widest crown was in the variant treated with the tank mixture $-98 \mathrm{~cm}$, which is $30 \mathrm{~cm}$ more than in the control.

Table 4. Biometric indicators of Thuja Brabant seedlings, 2016 - 2019.

\begin{tabular}{|c|c|c|c|c|c|c|c|c|c|}
\hline \multirow[b]{3}{*}{ Drug } & \multicolumn{9}{|c|}{ Colorado spruce (blue) } \\
\hline & \multicolumn{3}{|c|}{ Tree height, cm } & \multicolumn{3}{|c|}{ Trunk diameter, $\mathbf{c m}$} & \multicolumn{3}{|c|}{$\begin{array}{c}\text { Crown diameter, } \\
\text { cm }\end{array}$} \\
\hline & 2016 & 2018 & $\begin{array}{c}+,- \\
\text { to } \\
\text { co } \\
\text { ntr } \\
\text { ol } \\
\text { of }\end{array}$ & 2016 & 2018 & $\begin{array}{c}+,- \\
\text { to } \\
\text { contr } \\
\text { ol of }\end{array}$ & 2016 & 2018 & $\begin{array}{c}+,- \\
\text { to } \\
\text { co } \\
\text { ntr } \\
\text { ol } \\
\text { of }\end{array}$ \\
\hline Control (water) & 164 & 258 & - & 4.6 & 6.3 & - & 54 & 68 & - \\
\hline $\begin{array}{l}\text { Bordeaux liquid } \\
3 \%+\text { Zircon, } P \\
(0.1 \mathrm{~g} / 1)\end{array}$ & 196 & 267 & +9 & 4.9 & 6.8 & +0.3 & 67 & 73 & +5 \\
\hline $\begin{array}{l}\text { Fundazol, SP } \\
(500 \mathrm{~g} / \mathrm{kg})+ \\
\text { Epin-Extra, } \mathrm{P} \\
(0.025 \mathrm{~g} / \mathrm{l})\end{array}$ & 189 & 281 & +23 & 5.2 & 7.9 & +1.6 & 61 & 79 & +11 \\
\hline $\begin{array}{l}\text { Tilt, KE }(0.4 \%) \\
+ \text { Epin-Extra, P } \\
(0.025 \mathrm{~g} / \mathrm{l})\end{array}$ & 193 & 274 & +16 & 5.8 & 7.6 & +1.3 & 64 & 81 & +13 \\
\hline $\begin{array}{l}\text { Tank mix } \\
\text { (Fitosporin M, } \\
\text { AGAT-25 K, } \\
\text { TENSO cocktail, } \\
\text { BKK-9, poplar } \\
\text { bud extract) }\end{array}$ & 205 & 295 & +37 & 5.9 & 7.9 & +1.6 & 68 & 98 & +30 \\
\hline NSR 05 & 17.1 & 22.5 & & 0.35 & 0.81 & & 1.82 & 2.3 & \\
\hline
\end{tabular}

\section{Discussion}

An experiment with the testing the drugs belonging to different groups according to the class of chemical composition in combination with growth regulators, the use of a tank mixture of a complex composition showed that all of them had a stable positive effect on the effectiveness of therapeutic and prophylactic treatments and the restoration of slowly but surely the decorativeness of conifers within the line cities. The recovery went on for three years and we have shown the results in improving the biometric indicators of both common spruce, prickly spruce (blue), and Thuja Brabant. The common spruce turned out to be especially responsive, the height of its trunk increased in comparison with the control from 64 when treated with a mixture of Bordeaux liquid 3\% + zircon $\mathrm{cm}$ to $134 \mathrm{~cm}$ in the variant treated with a tank mixture. The increase in indicators for the diameter of the trunk and crown occurred in the same sequence: Bordeaux liquid $3 \%+$ zircon $>$ foundationol, $(500 \mathrm{~g} / \mathrm{kg})+$ epin-extra $>$ tilt, ke $(0.4 \%)+$ epin-extra $>$ tank mixture (phytosporin $\mathrm{M}$, AGAT-25 K, TENSO cocktail, BKK-9, poplar bud extract). Thuja Brabant reacted least of 
all to the methods used, the increase in biometric indicators was slower, and the reaction to the drugs itself was weaker.

\section{Conclusion}

The general condition, the quality of the needles, the power of the annual growth of the plants treated with the tested tank mixture are significantly better than those of the control plants.

The composition offered by us can be successfully used for therapeutic and prophylactic measures on all types of conifers, and also, possibly, after adjusting the recipe, and for many deciduous ornamental plants.

It was revealed that in the city it is not worth planting a capricious ordinary spruce, demanding for soil conditions and moisture, and does not tolerate strong gassed air. It is clearly not its place near busy highways and in the city center.

The beauties of western thuja and prickly spruce tolerate the smoke and gas pollution of the urban atmosphere better than other evergreen conifers, are very frost-resistant, prickly spruce is also drought-resistant, but demanding of light, thuja, on the contrary, is one of the most shade-tolerant species, but does not like drying out of the soil.

\section{References}

1. G.N. Gordeyeva, Izv. vuzov. Lesn. zhurn., 3 (2021)

2. Ye.V. Kalyuta, M.I. Mal'tsev, O.V. Shepeleva, Ye.V. Isayeva, Khimiya rastitel'nogo syr'ya, 4 (2017)

3. Ye.V. Isayeva, G.A. Lozhkina, YU.A. Litovka, T.V. Ryazanova, Khimiya rastitel'nogo syr'ya, 1 (2008)

4. S.K. Pentel'kin, Lesnoye khozyaystvo, 2 (2001)

5. Sanitarnyye pravila i normativy, SanPiN 1.2.2584-10 «Gigiyenicheskiye trebovaniya $\mathrm{k}$ bezopasnosti protsessov ispytaniy, khraneniya, perevozki, realizatsii, primeneniya, obezvrezhivaniya i utilizatsii pestitsidov i agrokhimikatov» (utv. postanovleniyem Glavnogo gosudarstvennogo sanitarnogo vracha RF), 17 (2010)

6. S. Wulff, Environmental Monitoring and Assessment, 184 (2012)

7. Grzywacz, Acta Societatis Botanicorum Poloniae, 42 (1973)

8. C. Davis, T. Meyer, Field guide to tree diseases of Ontario (2004)

9. F. Santini, New Phytologist, 297 (2013)

10. Stankevičiene, Problemy lesnoy fitopatologii i mikologii (Mater. 9-y Mezhdunar. konf. BGTU, 2015)

11. I.G. Semenkova, E.S. Sokolova, Phytopathology (Moscow, "Academy", 2003) 